\title{
The Immigration Puzzle in Italy: A Survey of Evidence and Facts
}

\section{Rama Dasi Mariani $^{1}$ (D) Alessandra Pasquini ${ }^{2} \cdot$ Furio Camillo Rosati $^{1}$ (D)}

Received: 17 November 2020 / Accepted: 17 August 2021 / Published online: 9 September 2021

(c) The Author(s) 2021

\begin{abstract}
Recently in Italy immigration has been at the centre of public debates. Nonetheless, the still growing literature has focused mainly on the experience of old settlement countries and has looked at single aspects of the phenomenon. In order to guide effective local policy intervention, we offer an exhaustive view of immigration in Italy. We combine the presentation of stylized facts from available data, based on descriptive analyses, with a review of existing studies. Our conclusions tell that evidence available for Italy does not match the policy relevance of the issue and also identify areas where solid evidence is needed.
\end{abstract}

Keywords Immigration · Mobility $\cdot$ Integration $\cdot$ Education $\cdot$ Regional labour market

JEL codes $\mathrm{F} 22 \cdot \mathrm{I} 24 \cdot \mathrm{J} 15 \cdot \mathrm{J} 61 \cdot \mathrm{R} 23$

\section{Introduction}

Migration has been at the centre of academic and policy debates, especially in the recent past. Several studies on this topic have been developed and they have generated substantial evidence on the impact of migration on countries of origin and destination and on migrants' welfare. ${ }^{1}$

The still growing body of evidence, however, is based on analyses focusing on the experience of a relatively small number of countries and has mainly looked at single aspects of the phenomenon, often guided by data availability and by policy

\footnotetext{
${ }^{1}$ For a recent review, see World Bank (2018).
}

Rama Dasi Mariani

mariani@economia.uniroma2.it

1 Centre for Economic and International Studies (CEIS), University of Rome "Tor Vergata", Via Columbia, 2, 00133 Rome, Italy

2 Regional Economic Research Division, L’Aquila Branch, Bank of Italy, L’Aquila, Italy 
relevance. While such an evidence increases our general knowledge on migration, it does not offer an exhaustive view with reference to individual countries. In fact, the external validity of the existing studies remains an open question.

Especially for policy purposes, a systematic overview of the different aspects of migration in a single country would be particularly useful. It would allow to assess if and to what extent the different effects identified in the literature are actually at stage and, consequently, it can offer the basis for a better assessment of the complementary adjustments induced by immigration.

This paper attempts to fill this gap by providing a survey of the evidence and analyses of different aspects of immigration in a specific country: Italy. To our knowledge, such an analysis has never been carried out for Italy or other countries. Existing surveys focus on a specific aspect and not with reference to a specific country. ${ }^{2}$

Migration is a very heterogeneous phenomenon, affecting in different ways different groups at different times: it requires adjustments for both immigrants and natives and it involves several aspects, such as residence, work and education. In analysing these three dimensions for the two population groups, we combine the presentation of stylized facts from available data with a review of existing studies. We think the former approach better suits an overview on immigrants' conditions, while the latter is necessary for an assessment of the overall effects of immigration on natives. In order to have an objective criterion we only present results of papers published in peer reviewed journals. This also allows to identify areas where solid evidence or analysis is lacking.

In the descriptive analysis we take advantage of the high granularity of a dataset built upon administrative data, provided at the municipality level (LAU2). ${ }^{3}$ The choice of the country is determined by the fact that in Italy immigration has become a relevant phenomenon only in the recent past, getting a great relevance in the political debate, ${ }^{4}$ and allowing us to take account of the very diverse frictions encountered at the beginning of the integration process.

The paper is divided in four sections. First, we present the basic facts about immigration in Italy. We also briefly discuss some issues relative to the definition of immigrant and its implication for the empirical analysis. In Sect. 3 we focus on the geographical distribution of immigrants and their effect of natives' displacement. In Sect. 4 we look at the education of young immigrants and natives, and in Sect. 5 we discuss the complex issues related to the labour market. Section 6 concludes. By doing so, hopefully we cover most of the potential effects of immigration on the destination economy identified by the literature and we provide an overall picture of the Italian immigration.

\footnotetext{
${ }^{2}$ For a review on the effect of immigration on wages and income distribution see e.g. Dustmann et al. (2016). For a review on the effect on wages and productive structure see e.g. Peri (2016).

3 The descriptive statistics relative to human capital are an exception since data are available at provincial level (NUTS3) only.

4 There is also evidence that immigration has an impact on voting outcomes (Barone et al., 2016).
} 


\section{The Basic Facts}

\subsection{Data and Definition of the Immigrant}

In economics, the immigrant status is mainly defined on the basis of citizenship or on the basis of the country of birth. In the present analysis, we follow the official definition used by the Italian National Statistical Office (Istat) and identify immigrants according to their citizenship. ${ }^{5}$ Therefore, immigrants are all the individuals who are not Italian citizens, are legally residing in Italy and are registered in a municipality. This excludes two important categories of immigrants: refugees and asylum seekers that did not register to the municipality of residence, and irregular immigrants. ${ }^{6}$

Differently to the citizenship, the definition based on the country of birth includes individuals born abroad who were naturalized and excludes individuals born in Italy who are not citizens. Because of the Jus Sanguinis, individuals born in Italy by foreign-born parents acquire the Italian citizenship only after turning 18. Therefore, while the foreign-born definition is the most appropriate in countries where the Jus Soli holds, the choice of the best immigrant definition is not straightforward in the case of Jus Sanguinis. Beside the quantitative implications, it is an open question which definition does capture better the immigrant status in socio-economic terms.

In the case of Italy, the stock of immigrants based on the country of birth exceeds by just less than one million that obtained using the citizenship criteria (see Table 1). A difference that almost coincides with the stock of citizenships granted from 2002 (see Fig. 1). Indeed, recently, the acquisition of citizenship has become an increasingly important phenomenon and for this reason we briefly discuss its characteristics and its implications for the analysis we carry out.

There are three main channels of naturalization in Italy: residency along with work experience, marriage, when native-born individuals of foreign origin turn 18 years. All three have played an important role in the process of naturalization (see Table 1) and, apart from marriage, they depend directly or indirectly on the length of stay in the country.

Figure 2 presents the number of citizenships granted in Italy in 2012 and 2018 by province. ${ }^{7}$ The high variability in the naturalization rate across provinces can reflect either a different composition of immigrants (e.g., with respect to their time of arrival or to the rate of Italian-born children of foreign origin) or different attitudes and efficiency of the local administration. From preliminary analyses, it does

\footnotetext{
${ }^{5}$ For the analysis on education, instead, we define immigrants with respect to the country of birth. For more details on data used in this paper see Appendix A.

6 In 2017 irregular migrants were about 490,000 according to the ISMU Foundation, while according to OECD (2018) the number of migrants living in Italy without a regular visa ranges from 279,000 to 461,000. Furthermore, dalla Pellegrina et al. (2018) show that the probability of regularization of migrants is higher after 2011.

7 Naturalization rate is computed over the number of non citizens.
} 
not appear to be correlated with the ethnic composition of the immigrant population living in the province. ${ }^{8}$

Beyond economic migrants, refugees and asylum seekers are also present in Italy. Their number is small with respect to that of the economic migrants (see Fig. 1), but in the period 2014-2018 they represented the only positive net flow from abroad. The implications of such inflows are still uncertain. They depend on the actual number of asylum seekers that receive the refugee status and are, therefore, allowed to freely move and work in the country.

According to the data from the European Asylum Support Office (EASO) in 2018 in Italy only 6,490 first-instance applicants received the refugee status while there were 64,540 rejections and the stock of pending cases amounted to 102,995. These figures are still very small to allow for an analysis of the differences with respect to economic migrants and also for a discussion on what will be the effects on the receiving population. Nonetheless, since the European migration crisis in 2015, forced migrants have been receiving most of the public attention in Italy, suggesting that what matters for attitudes towards immigration and, consequently, voting behaviours might be the dynamics rather than the actual numbers and figures of the phenomenon. ${ }^{9}$

\subsection{The Overall Picture}

In the recent past, the stock of immigrants living in Italy has reached the all-time high of just over 5 million. At the same time, the growth rate of the stock-albeit high in the earlier decade-substantially decreased since 2014 (see Fig. 3).

In 2018 , the share of the immigrant population with respect to the native population was about 9 per cent, with a relative higher concentration in the North and in the Centre (see Table 3). During this period the presence of immigrants increased relatively faster in the areas where they were less present-namely, in the South and in the Islands. Therefore, while in the years 2012-2018 there was a reduction in the rate of growth of immigration, the period was also characterized by a diffusion of the phenomenon over the Italian territory, possibly due also to the Italian Dispersal Policy of refugees that allocated them according to the criteria, inter alia, of the assessed capacity of local areas. Indeed, after 2014, when the number of refugees and asylum seekers increased, the newly issued Dispersal Policy has allocated them across the country on the basis of the province population. As refugees were allowed to register their presence, the observed diffusion can be due to this (relatively) new dimension of the phenomenon. ${ }^{10}$

The composition by country of origin of immigrants has been fairly stable in the recent past (see Table 2). Romanian, Albanian and Moroccan represented the largest communities in both 2012 and 2018, and the relative ranking in the top 10 countries

\footnotetext{
8 Results are available upon request.

9 For a similar conclusion on the case of UK see Levi et al. (2020).

${ }^{10}$ For an extensive description of the Italian Dispersal Policy and the potential effect of refugees on voting behaviors see Campo et al. (2020).
} 
Table 1 Immigration in Italy, definitions

\begin{tabular}{|c|c|c|c|c|c|c|c|}
\hline & \multicolumn{2}{|c|}{ Country of Birth (2018) } & \multicolumn{2}{|l|}{ Citizenship (2018) } & \multicolumn{3}{|c|}{ Naturalization (2012-2018) } \\
\hline & Stock (thousand) & Rate & Stock (thousand) & Rate & Residence & Marriage & Other \\
\hline Italy & 5883 & 9.78 & 4983 & 9.03 & 0.35 & 0.21 & 0.43 \\
\hline North-West & 1830 & 11.45 & 1681 & 11.76 & 0.36 & 0.21 & 0.43 \\
\hline North-East & 1444 & 12.50 & 1189 & 11.48 & 0.40 & 0.19 & 0.41 \\
\hline Centre & 1448 & 12.09 & 1280 & 11.96 & 0.32 & 0.24 & 0.44 \\
\hline South & 805 & 5.76 & 599 & 4.47 & 0.26 & 0.22 & 0.51 \\
\hline Islands & 356 & 5.35 & 233 & 3.63 & 0.21 & 0.29 & 0.49 \\
\hline
\end{tabular}

Source: Authors' elaboration on Labour Force Survey (LFS) in the first two columns and ISTAT data. Notes: Residence refers to naturalizations due to long-term permanence in Italy. Marriage refers to naturalizations due to marriage with an Italian citizen. Other refers to all other reasons, mainly Italian born of foreign origins turning 18 years old

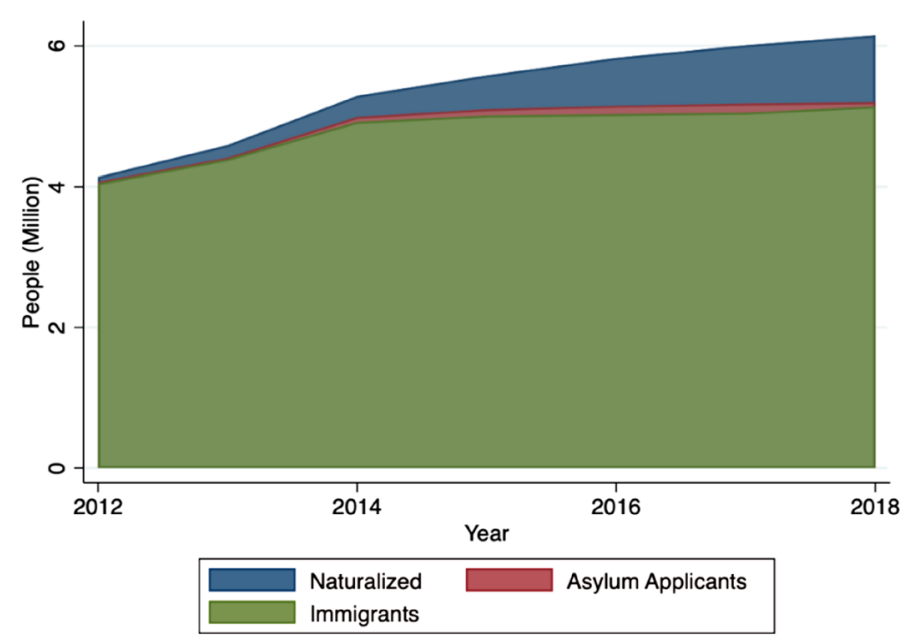

Fig. 1 Stock of population of foreign origin in Italy from 2012 to 2018 Source: Authors' elaboration on Eurostat data (for asylum applicants) and ISTAT data. Notes: The stock of naturalized immigrants, as aggregated flows, is computed starting from 2000 because of data availability

of origin presents only minor changes. Altogether, immigrants from the top 10 countries account for about 65 per cent of the total immigrant population. This suggests that immigration in Italy is relatively concentrated in terms of countries of origin with respect to old settlement countries, e.g. USA and Canada (OECD 2018). In the former, in 2018, the top 10 foreign nationalities accounted for less that 45 percent of total foreign-born population, in the latter for about 50 percent.

The last two columns of Table 2 show that ethnic composition of refugees and asylum seekers in Italy. Italy, along with Spain and Greece, is one of the main countries of first arrival in the European Union, whose members are the main destinations of asylum seekers among high-income countries (World Bank 2018). 


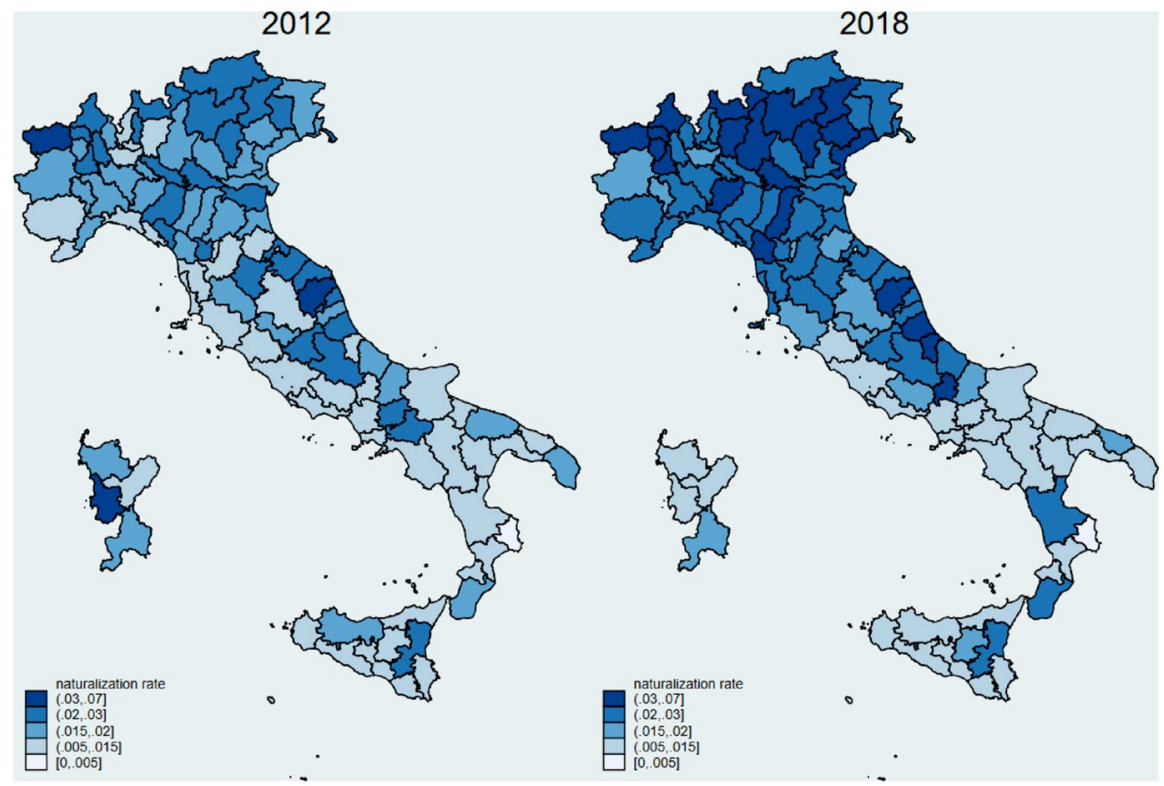

Fig. 2 Naturalization rate by province. Source: Authors' elaboration on ISTAT data. Notes: Naturalization rate is computed as the number of new citizens over non citizens

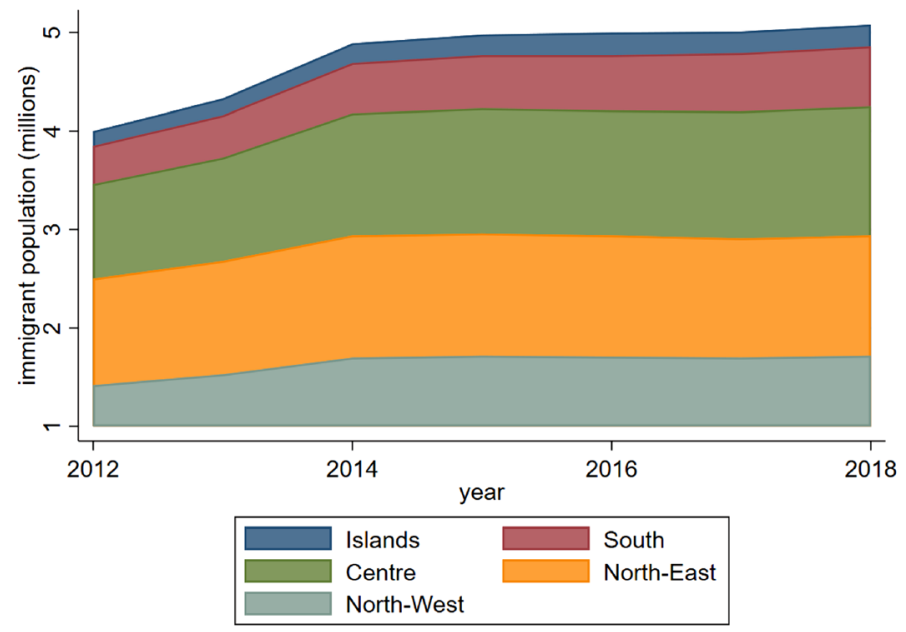

Fig. 3 Immigrant stock by area from 2012 to 2018. Source: Authors' elaboration on ISTAT data. Notes: Areas are classified according to NUTS 1 level

Thanks to the territorial disaggregation of our data, we can observe that immigrants are relatively more concentrated in the largest municipalities, where they accounted for about $14 \%$ of the native population in 2018-a substantial increase with respect to the $9 \%$ observed in 2012 (see Table 3). 
Table 2 Composition of Italian immigration by nationality (top 10 countries of origin)

\begin{tabular}{|c|c|c|c|c|c|c|c|}
\hline \multicolumn{4}{|l|}{ Immigrants } & \multicolumn{4}{|c|}{ Asylum applicants } \\
\hline & 2012 & & 2018 & & 2012 & & 2018 \\
\hline Romania & 20.90 & Romania & 23.30 & Pakistan & 14.99 & Pakistan & 14.24 \\
\hline Albania & 11.20 & Albania & 8.60 & Nigeria & 9.31 & Nigeria & 11.63 \\
\hline Morocco & 10.20 & Morocco & 8.20 & Afghanistan & 8.62 & Bangladesh & 9.02 \\
\hline China & 4.90 & China & 5.70 & Senegal & 5.42 & Ukraine & 5.12 \\
\hline Ukraine & 4.50 & Ukraine & 4.60 & Tunisia & 5.16 & Senegal & 5.11 \\
\hline Moldova & 3.30 & Philippines & 3.30 & Ghana & 4.87 & Mali & 4.11 \\
\hline Philippines & 3.20 & India & 3.00 & Somalia & 4.64 & El Salvador & 3.79 \\
\hline India & 3.00 & Moldova & 2.60 & Mali & 4.52 & Gambia & 3.79 \\
\hline Peru & 2.30 & Bangladesh & 2.60 & Eritrea & 4.24 & Morocco & 3.18 \\
\hline Poland & 2.10 & Egypt & 2.30 & Côte d'Ivoire & 3.63 & Côte d'Ivoire & 3.11 \\
\hline Total & 65.60 & Total & 64.20 & Total & 65.39 & Total & 63.11 \\
\hline
\end{tabular}

Source: Authors' elaboration on ISTAT data (Immigrants) on Eurostat data (Asylum applicants)

Table 3 Immigrant share in Italy by municipality size

\begin{tabular}{lll}
\hline Panel A & & \\
Municipality population & 2012 & 2018 \\
Italy & 7.32 & 9.33 \\
Less than 100,000 & 6.76 & 7.45 \\
Up to 250,000 & 7.06 & 9.06 \\
More than 250,000 & 9.52 & 14.04 \\
Panel B & & \\
Municipality population & 2012 & 2018 \\
Less than 100,000 & 29.20 & 24.41 \\
Up to 250,000 & 51.97 & 53.13 \\
More than 250,000 & 18.83 & 22.16 \\
\hline
\end{tabular}

Source: Authors' elaboration on ISTAT data. Notes: In Panel A the immigrant share by municipality size is computed as the percentage of the native population in the municipalities. In Panel B it is computed as the percentage of the total number of immigrants

\section{Geographical Allocation and Internal Mobility}

To identify some of the elements that characterize the geographical distribution of migrants we run a set of regressions to correlate the presence of immigrants to some characteristics of the area of residence. The results are presented in Table 4. 
Not surprisingly migrants tend to concentrate in municipality where per capita real income (as measures by tax returns) is higher. ${ }^{11}$ The correlation is not negligible, as the partial correlation implies that a 10 per cent higher per capita income is associated with a 5 per cent higher number of migrants. As shown in columns (2) and (3) a strong network effect appears to be present, as immigrants tend to concentrate also where others were already present independently from the economic condition of the area (as proxied by the per capita income $)^{12}$ : the correlation between the inverse hyperbolic sine transformation of the stocks is very high at 0.8 . On the other hand, the distance from the gateways of entry does not appear to be significantly correlated with the location of immigrants. Finally, immigrants appear to move towards those areas that are also destination of native population movements, again the partial correlation is high at about 0.7 .

Consistently with our results, Mocetti and Porello (2010) show that areas of residence are highly differentiated across nationalities and stable over time, pointing at a network effect and confirming that immigrants' choice about the province of destination appears not driven by local economic conditions alone. However, according to Mocetti and Porello (2010) the proximity to the frontiers played a key role, as most nationalities concentrated close to their gateways of entry. This effect does not appear to be presents in the more recent years (as discussed above) probably because of the change in the level and composition of migration flows.

With administrative data at municipality level, we can look in more detail and in a more refined way at the geographical segregation of immigrant population living in Italy. We compute a Residency Duncan Segregation Index for natives and immigrants. The index ranges from 0 (no segregation) to 1 (complete segregation) and Table 5 presents the Residency Duncan Segregation Index computed for the years 2012 and 2018. The degree of geographical segregation between immigrants and natives does not appear to be particularly high, indicating that both tend to concentrate in the same areas. The index is constant over time, showing only a marginal decrease from 0.28 in 2012 to 0.26 in 2018. This is in line with the Dunkan Index for the immigrant-native distribution across European Regions (NUTS-2), which for the EU15 Countries is on average 0.29 in 2018 (see e.g. Frattini and Campa, 2020).

Figure 4 shows the municipalities where immigrants are overrepresented with respect to natives. In purple are indicated the municipalities where the share of immigrants with respect to the total immigrant population is higher than the share of natives with respect to the total native population. Immigrants concentrate more, with respect to the native population, in the Centre-North of Italy. The number of municipalities where they are overrepresented decreased from 2012 to 2018.

Even if, on average, immigrants do not appear to be geographically segregated with respect to natives, individuals from different areas of origin tend to

\footnotetext{
11 The distribution of immigrants within European countries follows a similar pattern: in France, for instance, immigration rate in the region of Ile-de-France is $22 \%$ versus a national average of $12 \%$, and in UK immigration rate in the area of Greater London is $36 \%$ versus a national average of $14 \%$ (see Frattini and Campa, 2020).

12 The same result holds if we use the stock of immigrants at an earlier date (1990) and run, because of data limitations, the estimates at the province level.
} 
Table 4 Immigrants' presence determinats, OLS regressions

\begin{tabular}{llllll}
\hline & $(1)$ & $(2)$ & $(3)$ & $(4)$ & $(5)$ \\
& Immigrants & Immigrants & Immigrants & $\begin{array}{l}\text { Immigrants } \\
\text { Immigrant flows }\end{array}$ \\
\hline Real income & $0.578^{* * *}$ & & & \\
Immigrants (2011) & $(0.0362)$ & & & & \\
& & $0.821^{* * *}$ & & & \\
Immigrant flows (2011) & & $(0.00516)$ & & & \\
& & & $0.253^{* * *}$ & & \\
Distance to gateways & & $(0.00844)$ & & 0.00655 & \\
& & & & $(0.0127)$ & \\
Native internal inflows & & & & & $0.705^{* * *}$ \\
& & & & & \\
Natives & $0.294^{* * *}$ & $0.157^{* * *}$ & $0.262^{* * *}$ & $0.293^{* * *}$ & $\left.-0.413^{* * *}\right)$ \\
& $(0.0380)$ & $(0.00625)$ & $(0.0361)$ & $(0.0380)$ & $(0.0454)$ \\
Observations & 7,695 & 7,639 & 7,639 & 7,693 & 7,695 \\
$R$-squared & 0.882 & 0.972 & 0.894 & 0.882 & 0.832 \\
Controls & Yes & Yes & Yes & Yes & Yes \\
Municipality size FE & Yes & Yes & Yes & Yes & Yes \\
Macroarea FE & Yes & Yes & Yes & Yes & Yes \\
\hline
\end{tabular}

Source: Authors' elaboration on ISTAT data. Notes: Controls include real income (with the exception of model in column 1), municipality surplus, native and immigrant demographic balances and native population. Since we apply the Inverse Hyperbolic Sine transformation to all variables, coefficients can be interpreted as elasticities

$* * * p<0.01, * * p<0.05, * p<0.1$

concentrate in different areas of the country. The segregation index for each pair of areas of origin (see Table 6) is around 0.4 for most of the pairs, indicating a substantial degree of geographical segregation across nationalities.

Once in Italy, immigrants show a higher internal mobility than natives. Figure 5 illustrates the size and direction both of immigrants' net flows across Italian municipalities (Fig. 5, right-hand panel) and immigrants' net flows from abroad (Fig. 5, left-hand panel) aggregated over the period 2012-2018. In most of the municipalities of the Centre and North of Italy, where the number of immigrants arrived from abroad already increased from 2012 to 2018, internal net flows are positive.

Most of the largest metropolitan areas and the surrounding municipalities present high net inflows, both internal and international. Milan is an exception being characterized by a negative net flow, differently from its surrounding municipalities, suggesting a movement of the immigrant population to the suburbs. Negative internal net flows (on the right-hand panel) are experienced in the municipalities of Puglia, Calabria and Sicily that are often a port of entry for immigrants, as evident from the left-hand panel of Fig. 5.

The pattern of immigrants' internal flows is observed also at a more aggregated level (see the subsequent analysis) and in the EU. According to Frattini and Campa 
Table 5 Geographical segregation index of immigrants with respect to native, by year

\begin{tabular}{ll}
\hline Years & Duncan index \\
\hline 2012 & 0.28 \\
2018 & 0.26
\end{tabular}

Source: Authors' elaboration on ISTAT data
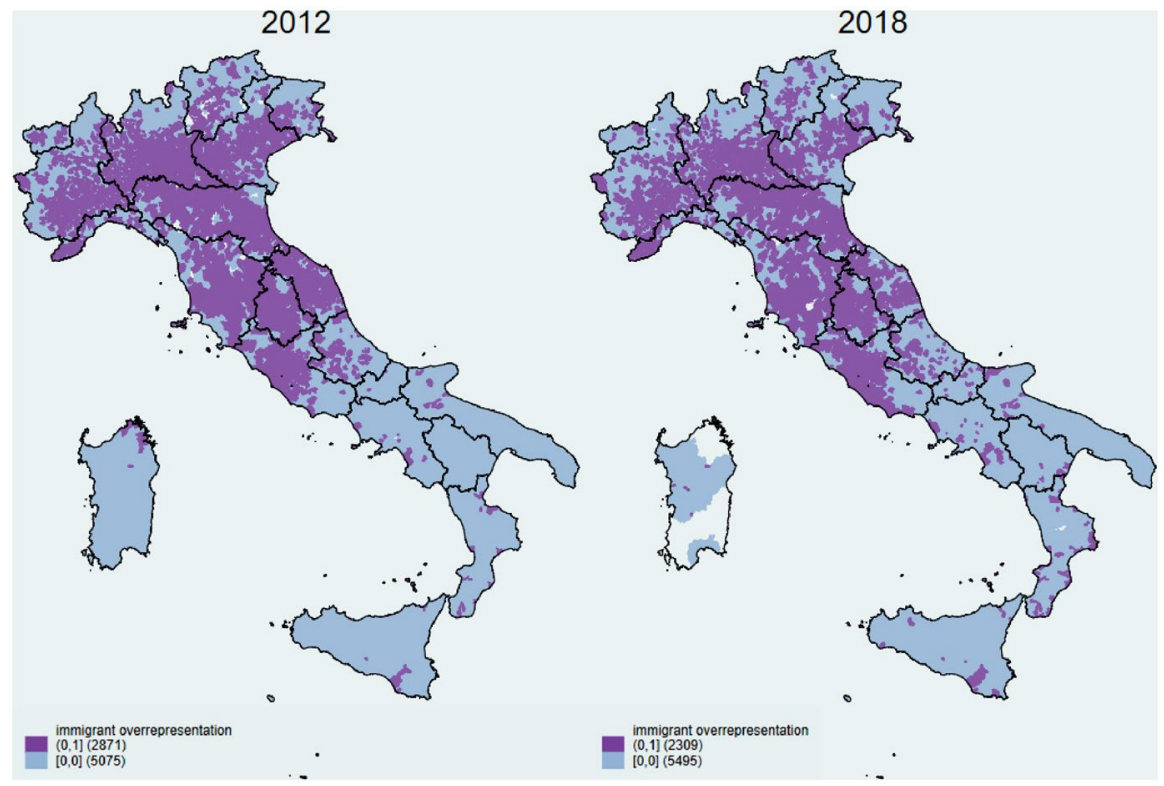

Fig. 4 Immigrant overrepresentation by municipality. Source: Authors' elaboration on ISTAT data. Notes: In purple municipalities where the share of residing immigrants with respect to the total of immigrants is higher than the natives' equivalent

Table 6 Pairwise residency duncan segregation index by area of origin

\begin{tabular}{|c|c|c|c|c|c|c|}
\hline & Africa & South America & Asia & Europe & High Income & Native \\
\hline Africa & 0 & & & & & \\
\hline South America & 0.409 & 0 & & & & \\
\hline Asia & 0.376 & 0.377 & 0 & & & \\
\hline Europe & 0.283 & 0.424 & 0.4 & 0 & & \\
\hline High Income & 0.415 & 0.372 & 0.378 & 0.367 & 0 & \\
\hline Native & 0.315 & 0.468 & 0.423 & 0.261 & 0.38 & 0 \\
\hline
\end{tabular}

Source: Authors' elaboration on ISTAT data. Notes: The reference year is the 2018. High-income countries include: EU15, EU EFTA, North America and Oceania. Europe includes all EU countries excluding those in EU15 


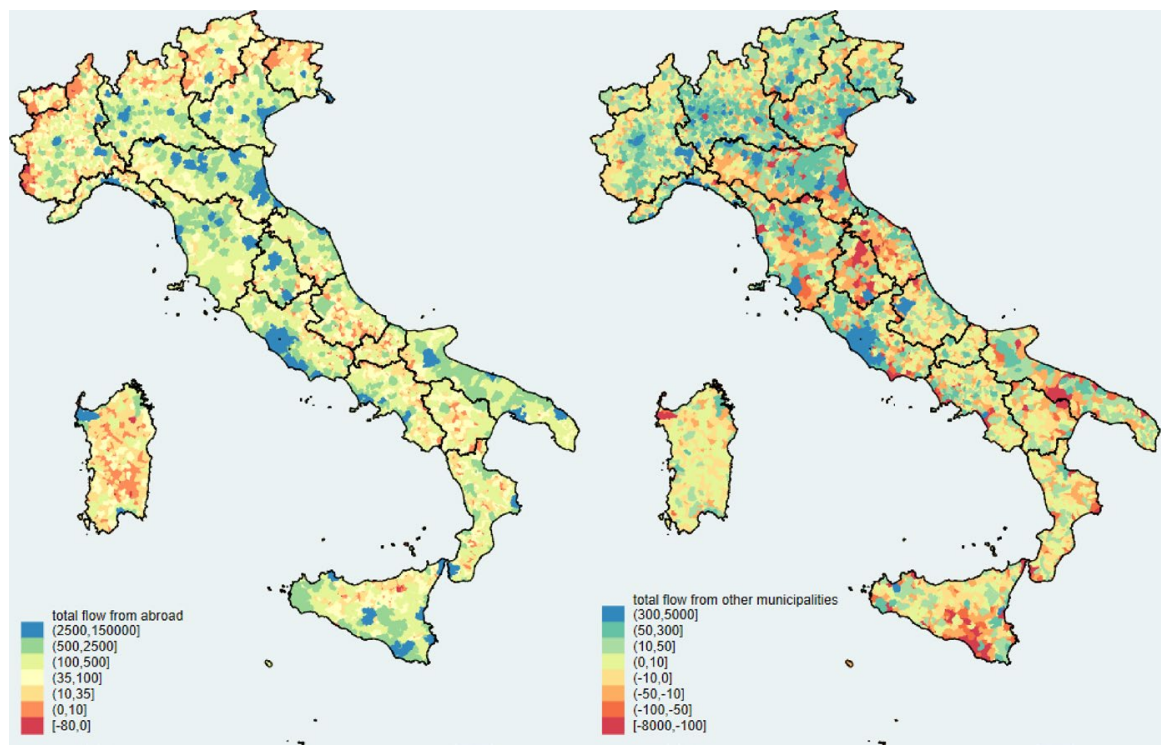

Fig. 5 Immigrant flows from abroad (left) and from other municipalities (right). Cumulated flows over the period 2012-2018. Source: Authors' elaboration on ISTAT data

(2020), not all migrants reach their final destination directly from the country of origin. $10 \%$ of them are considered "transit" migrants and, in the years 2016-2018, they have moved from their first country of arrival to a different EU country. Nonetheless, multi-steps migration is more common in Centre and North Europe and for migrants whose source countries are relatively close in terms of geographical distance and/or cultural proximity. In 2018 in Italy "transit" migrants account only for $3 \%$ of non EU-migrants. ${ }^{13}$

In Table 7 inflows, outflows and net flows of natives and immigrants across macro areas are reported separately. The immigrants' in- and out-flows are approximatively the double of those of natives in most of the areas. The gross (in or out) flows are of an order of magnitude larger than the net flows. However, they decreased sharply between 2012 and 2018-a possible explanation is that the reduction of net flows from abroad in the period, reduced the need for subsequent reallocation across macro areas. Table 8 presents the internal migration flows (as the share of the relevant population group) by municipality size for 2018. The net flows of immigrants are negative for large municipalities, ${ }^{14}$ while they are positive for small and midsize municipalities. ${ }^{15}$ Again, immigrants flows are larger than those of natives.

\footnotetext{
$\overline{13}$ see Frattini and Campa (2020) p. 40.

14 Note that the group of larger municipalities in the table is broader than those of the big metropolitan areas experiencing positive net flows according to Fig. 5.

15 Contrary to what expected, the net internal flows are not zero for Italy, since the observation of the inflow and that of the outflow are not simultaneous (see https://www.istat.it/it/archivio/226919).
} 
Table 7 Internal flows by macro area, immigrant status and year (as percentage of the relevant population)

\begin{tabular}{|c|c|c|c|c|c|}
\hline \multirow[t]{2}{*}{ Area } & \multirow[t]{2}{*}{ Flow } & \multicolumn{2}{|c|}{ Immigrants } & \multicolumn{2}{|l|}{ Natives } \\
\hline & & 2012 & 2018 & 2012 & 2018 \\
\hline \multirow[t]{3}{*}{ North-West } & In & 7.58 & 5.31 & 3.27 & 2.92 \\
\hline & Out & 7.18 & 5.05 & 3.12 & 2.75 \\
\hline & Net & 0.40 & 0.26 & 0.15 & 0.17 \\
\hline \multirow[t]{3}{*}{ North-East } & In & 7.04 & 5.68 & 2.90 & 2.75 \\
\hline & Out & 6.88 & 5.18 & 2.76 & 2.54 \\
\hline & Net & 0.16 & 0.50 & 0.14 & 0.21 \\
\hline \multirow[t]{3}{*}{ Centre } & In & 6.24 & 3.77 & 2.68 & 2.01 \\
\hline & Out & 6.02 & 3.84 & 2.44 & 2.00 \\
\hline & Net & 0.22 & -0.07 & 0.24 & 0.01 \\
\hline \multirow[t]{3}{*}{ South } & In & 6.56 & 4.08 & 1.95 & 1.57 \\
\hline & Out & 6.51 & 5.04 & 2.25 & 1.94 \\
\hline & Net & 0.05 & -0.96 & -0.30 & -0.37 \\
\hline \multirow[t]{3}{*}{ Islands } & In & 6.18 & 3.87 & 2.04 & 1.60 \\
\hline & Out & 6.30 & 4.58 & 2.21 & 1.92 \\
\hline & Net & -0.12 & -0.71 & -0.17 & -0.32 \\
\hline
\end{tabular}

Source: Authors' elaboration on ISTAT data. Notes: Native flows are expressed as a percentage of the geographical area's native population. Immigrant flows are expressed as a percentage of the geographical area's immigrant population

Nonetheless, given the smaller size of immigrant population, the number of natives moving across areas is much larger than that of immigrants.

Only a few studies analyse the differences between immigrant and native internal movements in Italy. Again, the study by Mocetti and Porello (2010) on the internal movements of immigrants across Italian Provinces for the period 1995-2005 reaches conclusions substantially in line with those presented in this section. Also, the directions of flows are confirmed-the net flows are positive in the North-West, the North-East and the Centre and negative in the South and the Islands.

Incentives to migrate internally also depends on the circumstances of immigrants, especially as far as their legal status is concerned. For example, Cozzolino et al. (2018) suggest that amnestied immigrants ${ }^{16}$ show the highest probability of moving. Nonetheless, the difference with respect to the other groups is small, especially with respect to other immigrants. The authors conclude that the higher mobility of immigrants could imply a more efficient allocation of them and, as a consequence, a higher permanence in the formal labour market. In the Euro area and in the USA

\footnotetext{
16 immigrants hired for the first time in 2002 thanks to amnesty program implemented by the Italian government aiming at regularizing immigrant workers employed in the informal labour market from at least three months (D.L. 195/2002).
} 
Table 8 Internal flows by municipality size and immigrant status (2018)

\begin{tabular}{llcr}
\hline Municipality type & Flow & Immigrants & Natives \\
\hline Less than100,000 & In & 7.09 & 2.64 \\
& Out & 6.97 & 2.71 \\
& Net & 0.12 & -0.07 \\
Up to 250,000 & In & 4.93 & 2.22 \\
& Out & 4.67 & 2.23 \\
More than 250,000 & Net & 0.27 & -0.01 \\
& In & 1.88 & 1.57 \\
& Out & 2.47 & 1.62 \\
& Net & -0.59 & -0.05 \\
\hline
\end{tabular}

Source: Authors' elaboration on ISTAT data. Notes: Native flows are expressed as a percentage of the geographical area's native population. Immigrant flows are expressed as a percentage of the geographical area's immigrant population

there is also evidence of a positive effect of immigrants' higher internal mobility on labour market efficiency (see e.g. Cadena and Kovak, 2016 and Basso et al., 2019).

Albeit immigrants and natives tend to move toward similar locations, natives' location decisions appear also to be affected by the flows of immigrants. A few papers have analysed the impact of immigration on native displacement in Italy. Brücker et al. (2011) look at the impact of immigrants on the internal mobility of natives by means of a theoretical model suggesting that a larger stock of immigrants in the North might affect the incentive for natives to move through its effect on wages, unemployment, house prices, congestion and criminality.

Mocetti and Porello (2010) look at the impact of the presence of immigrants on natives' interregional mobility for the period 1995-2005. They identify a displacement effect on low-educated natives, while highly educated individuals are attracted by regions with a higher immigration rate. This is confirmed by the very recent results by Basile et al. (2021) that show a substitutability between new immigrants' and low-educated incumbents, both natives and foreigners, and a complementarity with high-educated ones.

\section{Human Capital}

Immigrants' education gap provides the most important information on integration, especially from an intergenerational and long-term perspective. A first indicator is given by the distribution of native and immigrant students across grades. Following Murat (2012), we compute the ratio between the share of immigrants (separately for the first and the second generation) and the share of natives in the same grade. Table 9 shows the results for grade 2 and 10. The relative distribution of first-generation immigrants is strongly skewed towards secondary education (Grade 10), most likely because they tend to be relatively older than natives. On the contrary, the 
relative distribution of second-generation students is very similar to that of natives (the values of the indicator are close to 1 ).

Immigrants' school performances, as measured by the INVALSI test scores, show substantial differences among the three groups. The last two columns of Table 9 presents the difference in test scores between immigrants and natives as a percentage of natives' scores. Immigrants' learning gap is relatively large and remains relevant, albeit slightly lower, also for second generation students.

These differences do not appear to be linked to the characteristics of immigrants' area of residence. As Table 10 shows at provincial level the correlation between migrants' and natives' test scores is close to one, with the observed difference mainly explained by the constant term. This also implies that the gap with respect to natives' test scores is relatively larger in low performing provinces.

Several studies analyse the immigrant education gap in Italy. Most of them focuses on test scores in standardized assessment tests. Murat (2012) uses the 2006 test scores collected by the Programme for International Student Assessment (PISA). The gap between native and immigrant education outcomes can be due to a different composition of the two groups (i.e. different socio-economic background, school type, age, gender, etc.) or, it can be due to the immigrant status per se. ${ }^{17}$ Once Murat (2012) controls for students' socio-economic characteristics, school type (lyceums, technical and vocational schools) the results suggest that immigrants with the same socio-economic background and attending the same school type of the native group experience a small learning gap.

Di Liberto (2015) finds that the length of stay in Italy greatly affects the school performance of immigrants' children. Once controlled for background characteristics_-including the language spoken at home - the largest learning gap with respect to natives is observed for students who have been in Italy for 1 year or less. For the others the learning gap is substantially reduced, but not fully eliminated.

We replicate one of the regressions by Di Liberto (2015) with more recent data from INVALSI. ${ }^{18}$ The coefficients, estimated separately for first- and second-generation immigrants, are presented in Fig. 6. The dependent variable is the standardized reading test score, ranging between 0 and 100. Therefore, the immigrant gap can be interpreted as a percentage gap with respect to the maximum score. All the coefficients are negative and significant, indicating that the gap between natives' and immigrants' test scores persists even after background characteristics are controlled for. The gap appears to be decreasing from the academic year 2014-2015 consistently with the unconditional means presented in Table 9.

Barban and White (2011) focus on the heterogeneity of the learning gap by ethnicity and show that the gap is especially large for children coming from Yugoslavia, Morocco, Tunisia and Macedonia, while children coming from China perform better than natives, independently from the length of permanence in Italy. However, their results should be taken with caution since the final exam is not perfectly standardized at the national level.

\footnotetext{
17 See Borjas (1992) for a more accurate discussion about the ethnic capital.

18 Additional details on the estimates are available on request.
} 
Table 9 Immigrant students' distribution and learning gap by grade, generation and academic year

\begin{tabular}{|c|c|c|c|c|c|c|c|c|}
\hline \multirow[t]{2}{*}{$\begin{array}{l}\text { Academic } \\
\text { year }\end{array}$} & \multicolumn{2}{|c|}{$\begin{array}{l}\text { (1) } \\
\text { Grade } 2\end{array}$} & \multicolumn{2}{|c|}{$\begin{array}{l}\text { (2) } \\
\text { Grade } 10\end{array}$} & \multicolumn{2}{|l|}{$\begin{array}{l}\text { (3) } \\
\text { First }\end{array}$} & \multicolumn{2}{|l|}{$\begin{array}{l}\text { (4) } \\
\text { Second }\end{array}$} \\
\hline & First & Second & First & Second & Grade 2 & Grade 10 & Grade 2 & Grade 10 \\
\hline $2012 / 13$ & 0.64 & 1.29 & 1.45 & 0.64 & -15.1 & -15.0 & -8.7 & -12.3 \\
\hline 2017/18 & 0.53 & 1 & 1.50 & 1 & -19.5 & -10.5 & -12.7 & -9.0 \\
\hline
\end{tabular}

Source: Authors' elaboration on INVALSI data. Notes: The share of immigrant students is computed with respect to the total amount of immigrants in all grades. The share of native students is computed with respect to the total amount of native students in all grades

Table 10 Relationship between migrants' and natives' test scores by province

\begin{tabular}{lll}
\hline & Reading scores & Mathematics scores \\
\hline Natives' scores & $0.919 * * *$ & \\
& $(0.00274)$ & \\
Natives' scores & & $0.922 * * *$ \\
& & $(0.00237)$ \\
Constant & $-3.394 * * *$ & $-2.458^{* * *}$ \\
& $(0.214)$ & $(0.174)$ \\
Observations & 1,506 & 1,506 \\
$R$-squared & 0.987 & 0.990 \\
\hline
\end{tabular}

Source: Authors' elaboration on INVALSI data. Notes: the reference academic year is the 2016/17. Standard errors in parentheses. $* * * p<0.01, * * p<0.05, * p<0.1$

As already mentioned, an important dimension of the discrepancy in human capital accumulation between natives and immigrants concerns the choice of the school type. Italy is a country of early tracking, at age 13, pupils choose between different school types (lyceums, technical schools and vocational schools). Lyceums are more academically oriented. Vocational schools are work-oriented, they can last 2 years less than the other types and prepare children for a specific job. Technical schools are in-between lyceums and vocational schools, offering children a more technical background together with a basic readiness for tertiary education. Table 11 presents the distribution of native and immigrant students across high school types and its change over time.

Natives have the highest percentage of enrolment in lyceums, followed by second-generation immigrants, while first-generation immigrants are more likely to be enrolled in vocational or technical education. This distribution is stable across years with the exception of the first generation, whose enrolment in lyceums increases at the expenses of vocational schools. ${ }^{19}$

\footnotetext{
${ }^{19}$ See Appendix B to have an overview on the distribution of native and immigrant students across the different school types disaggregated by province.
} 


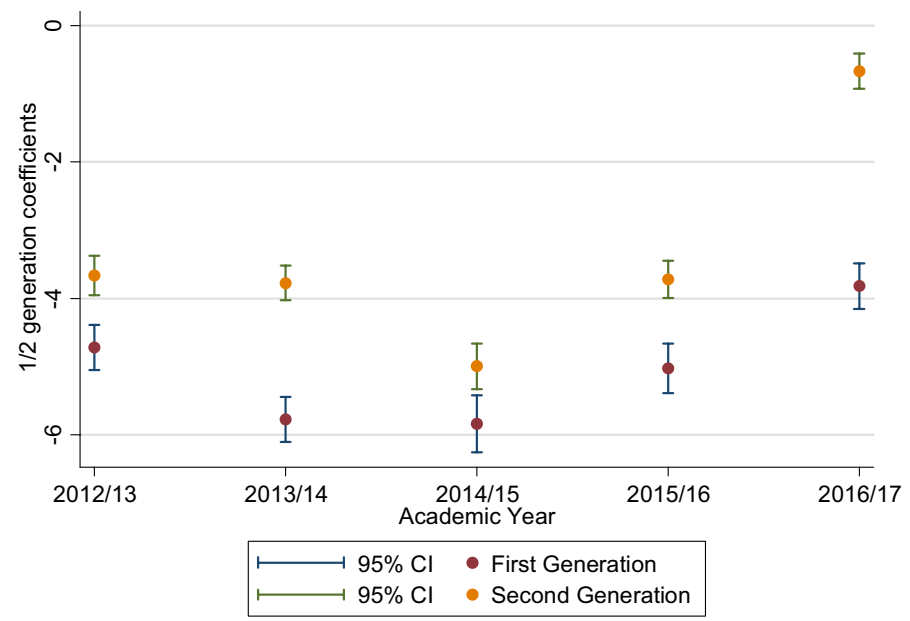

Fig. 6 Coefficients of first- and second-generation immigrant status. Source: Authors' elaboration on INVALSI data. Notes: The outcome is reading test scores and the reference grade is 10th

Several studies have analysed immigrant children's high-school choice. Barban and White (2011) show that first-generation students have the lowest probability to be enrolled in technical schools or lyceums. Similarly, Bertolini et al. (2015) find that immigrants have a lower probability to be enrolled in upper-secondary school in general, a lower probability to be enrolled in lyceums and a higher probability to be enrolled in vocational schools.

The presence of immigrant students lagging behind can have an impact on native peers as well. For example, immigrant students can require additional efforts from teachers (i.e. because of higher linguistic difficulties or to foster integration), who have then less remaining time for the other students. Moreover, in presence of several students lagging behind, teachers can decide to lower the standard of the whole group. Contini (2013) estimates the impact of having immigrant peers on native children's educational outcome and finds a small negative impact of the share of immigrants in the classroom on children's reading scores and no significant impact on mathematics scores. At the same time, she finds a positive impact of the presence of second-generation immigrant peers. However, both the positive and the negative effects are small compared to the average test scores. The author shows that at least 40 per cent of the negative impact of the first-generation immigrants is due to peer characteristics rather than peer achievements. Similarly, Tonello (2016) shows that the low performing children are affected the most by the number of immigrants in the same classroom, while Ballatore et al. (2018) find a negative and significant effect of $16 \%$ of natives' score standard deviation due to the number of immigrant students in the classroom. 


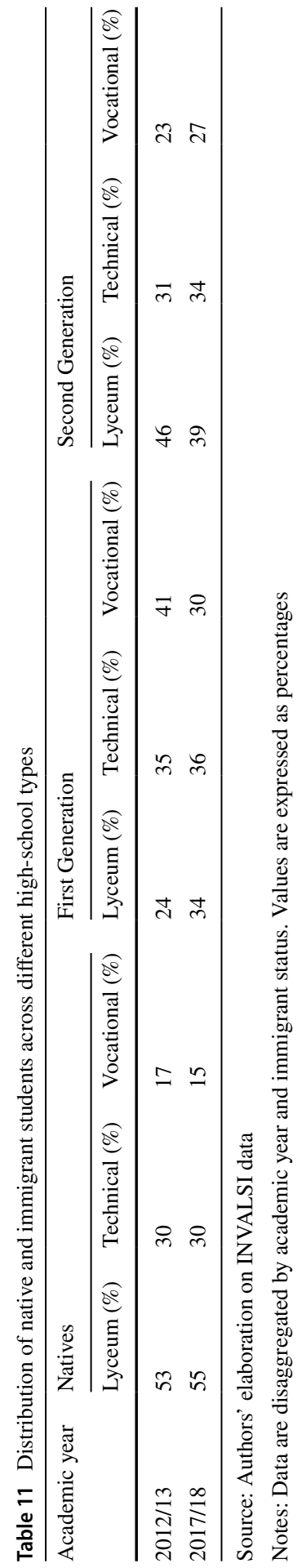




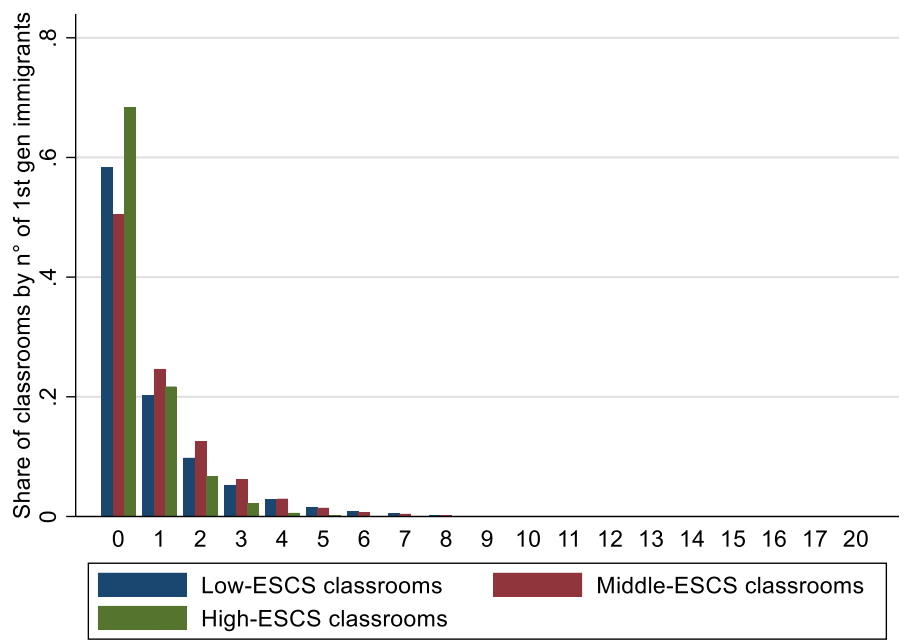

Fig. 7 Immigrant students' presence by socio-economic level. Source: Authors' elaboration on INVALSI data. Notes: The average ESCS was calculated excluding immigrant children. On the horizontal axis we report the number of immigrant students of 1 st generation in the classroom. Average over the period 2011-2016 (data did not differ much between 1 year and the others). Reference Grade: 10th

Table 12 First-generation students by socio-economic level

\begin{tabular}{lll}
\hline Socio-economic level (ESCS) & $\begin{array}{l}\text { Average number of 1st generation } \\
\text { immigrants }\end{array}$ & $\begin{array}{l}\text { Average number of 1st } \\
\text { generation immigrants } \\
\text { (excluding 0) }\end{array}$ \\
\hline Low & 0.88 & 2.12 \\
Middle & 0.99 & 2.01 \\
High & 0.46 & 1.45 \\
\hline
\end{tabular}

Source: Authors' elaboration on INVALSI data

Notes: The average ESCS is calculated excluding immigrant children. Average across years 2011-2016 (data did not differ much between one year and the others). Reference Grade: 10th

Frattini and Meschi (2019) estimate the immigrant peer effect in vocational schools. This is a case of particular relevance, given the large share of immigrants attending vocational schools, along with a higher concentration of low performing students (Pasquini and Rosati, 2019). They find no effect on reading scores and a small effect on mathematics scores for the group of natives, but a larger effect for native students in the lowest half of the ability distribution. The results also point at a non-linear effect significant only in classrooms with a large share of immigrants also linked to the average linguistic distance between foreign-born and native students.

The results just discussed indicates that low performing students are more likely to be negatively affected by the presence of immigrant peers. In Fig. 7, the share of classroom by number of immigrants is presented separately for the average 
socio-economic index of the natives in the classroom: lower than the first tercile (low-ESCS classes), between the first and the second (middle-ESCS classes) and higher than the second (high-ESCS classes). The lowest socio-economic levels are associated with the highest immigrants' presence. Therefore, immigrants tend to concentrate in the classrooms where their impact is higher. Similarly, Table 12 displays the number of immigrant students by socio-economic category of the classroom. The average number of first-generation immigrant students clearly varies inversely with respect to the average socio-economic status of the group.

Taken together the presented results-pointing at a negative impact of immigrant presence that is higher when the number of immigrant students is particularly high and affecting especially low-performing natives-require a policy action addressed to students with a disadvantaged background, with no distinction on the ethnic origin. This is a common pattern among the European countries (see e.g. Brunello and De Paola, 2017), while the relatively higher presence of first-generation students with respect to the second-generation is typical of a recent immigration country like Italy.

\section{Labour Market}

From 2012 to 2018, in Italy, immigrant workers concentrated mostly in Manufacturing, Construction, and Other services (Table 13, last two columns). The latter also includes services to the households. As shown in the first two columns of Table 13, immigrants represent a relatively high share of total employment in Agriculture, Construction, Accommodation and, especially, in Other services. By a comparison with Table 14, where we present the ratio of white-collar workers over blue-collar workers, it is easy to grasp that immigrants are overrepresented in relatively lowskilled sectors. Transportation and storage is the only exception.

The high presence of immigrants in the sector of services to the households is observed only recently, most likely following the EU Enlargement to Romania and Bulgaria in 2007 (see e.g. Mariani and Rosati 2021). ${ }^{20}$ In 2000, in Italy, immigrants represented only the $5 \%$ of total employment of the sector and $4 \%$ of them was employed in it. In the same year, in the OECD countries, they accounted for the $13 \%$ of the employment in the services to the households and the sector employed $10 \%$ of them (see Tables 15 and 16 in Appendix).

Some studies have analysed the labour market integration of immigrant workers compared to natives. They focus on the difference between labour market outcomes not explained by differences in education or experience. For example, Fullin and Reyneri (2011) describe immigrant workers as not penalized in terms of employment rate but segregated in manual jobs even after controlling for formal education. Ceccarelli et al. (2014) show that second-generation immigrants perform more similarly to first generation than to natives in 2012 than in

\footnotetext{
${ }^{20}$ For other papers that discuss the consequences for Italy of the EU Enlargement in 2007 see Mastrobuoni and Pinotti (2015) and Adamopoulou and Kaya (2019).
} 
Table 13 Immigrants in employment

\begin{tabular}{|c|c|c|c|c|}
\hline & \multicolumn{2}{|c|}{$\begin{array}{l}\text { Immigrant-native ratio } \\
\text { by sector }\end{array}$} & \multicolumn{2}{|c|}{$\begin{array}{l}\text { Immigrants' distri- } \\
\text { bution by sector }\end{array}$} \\
\hline & 2012 & 2018 & 2012 & 2018 \\
\hline Agriculture, forestry and fishing & 12.90 & 15.66 & 5.02 & 5.92 \\
\hline Manufacturing & 8.25 & 9.50 & 19.32 & 19.27 \\
\hline Construction & 17.69 & 15.58 & 15.55 & 9.74 \\
\hline Wholesale and retail trade & 4.83 & 6.26 & 8.12 & 9.08 \\
\hline Accommodation and food service activities & 14.73 & 16.85 & 8.44 & 9.69 \\
\hline Transportation and storage & 9.22 & 9.83 & 4.94 & 4.73 \\
\hline Information and communication & 1.34 & 3.08 & 0.40 & 0.80 \\
\hline Financial and insurance activities & 0.28 & 0.54 & 0.09 & 0.16 \\
\hline Real estate activities & 6.97 & 6.11 & 7.99 & 7.08 \\
\hline Public administration and defense & 0.00 & 0.00 & 0.00 & 0.00 \\
\hline Education, human health and social work activities & 3.14 & 3.05 & 5.41 & 4.98 \\
\hline Other services & 30.19 & 36.69 & 24.73 & 28.53 \\
\hline
\end{tabular}

Source: Authors' elaboration on LFS data. Notes: Sectors are defined as in NACE rev.2 classification and aggregated into 12 categories by ISTAT

2007. Therefore, the authors conclude that the integration process slowed down in the period under analysis. D'Agostino et al. (2016) look at differences in wages across ethnic groups and they find that nearly all the inequality is explained by the within-group component. They also observe that, among the immigrant population, the median income is the highest for Filipinos, but it is not significantly different from Albanians, Moldovans and Moroccans' income. On the contrary, the Ukrainians have the lowest median income.

Over-education is a well-documented characteristic of immigrant workers. In a framework of asymmetric information, the education achieved abroad can be a signal of the unobserved productivity weaker than the education acquired in the country of residence. Another explanation is that formal education can be poorly transferable across countries, mainly because of linguistic barriers. In both cases, years of experience in the destination country should reduce the immigrantnative gap in over-education. Conversely, Dell'Aringa and Pagani (2011) show that immigrants' overeducation is not affected by the number of years spent in Italy. Fellini et al. (2018), however, observe that especially for highly educated immigrants from new EU member States experience tends to reduce overeducation relatively quickly, as shown by the upward mobility of this group.

Probabily the most debated issue related to immigration is the labour market effect of newly arrived workers. According to the theoretical framework by Hanson and Slaugher (2002), the labour market can absorb a labor-supply shock, like the arrival of new immigrants, through three non-mutually exclusive mechanisms: a change in wages, a change in the output composition, and a change in technology. More specifically, following a shift in the labour supply, the market can adjust by reaching a new equilibrium along the labour demand-with higher 
Table 14 Ratio of white- over blue-collar workers by NACE sectors

\begin{tabular}{lll}
\hline & 2012 & 2018 \\
\hline Agriculture, forestry and fishing & $\mathbf{8 . 1 6}$ & $\mathbf{5 . 9 8}$ \\
Manufacturing & $\mathbf{3 2 . 7 1}$ & $\mathbf{3 1 . 8 1}$ \\
Construction & $\mathbf{1 7 . 9 1}$ & $\mathbf{1 8 . 3 5}$ \\
Wholesale and retail trade & 55.92 & 54.74 \\
Accommodation and food service activities & $\mathbf{2 8 . 9 5}$ & $\mathbf{2 0 . 7 4}$ \\
Transportation and storage & 50.35 & 44.60 \\
Information and communication & 93.50 & 93.44 \\
Financial and insurance activities & 98.86 & 99.42 \\
Real estate activities & 63.17 & 60.38 \\
Public administration and defense & 93.02 & 94.72 \\
Education, human health and social work activities & 85.08 & 82.72 \\
Other services & $\mathbf{3 2 . 2 8}$ & $\mathbf{2 7 . 0 7}$ \\
\hline
\end{tabular}

Source: Authors' elaboration on LFS data. Notes: The share is computed as ratio of white collars over blue collars by sector. In bold font we represent sectors where immigrants are overrepresented with respect to natives (see the first two columns of Table 13). Sectors are classified by NACE rev. 2 classification and aggregated into 12 categories by ISTAT

employment and lower wage — or the supply shock can induce a shift in the labour demand, leading to an ambigous effect on wages and employment. The shift in the demand curve can occour through a change in the output mix and/or in technology - the output of more labour-intensive firms increases and/or every production unit uses labour in a more intensive way.

In open economies, if factor price equalization holds, we would observe an adjustment based only on employment. Therefore, it's more likely that firms operating in the tradable sector accommodate the increased supply by a change in the output or a change in the technology, while firms operating in the non tradable sectors adjust by a change in wage.

The effect of immigration on natives' wages has been the core subject explored by labour economists that have extensively analysed the case of the USA. The existing studies have reached controversial results that depend mainly on the specification of the estimated models. ${ }^{21}$ Analyses of the Italian case are rather scant. Gavosto et al. (1999) and Venturini and Villosio (2006) are among the few studies that try to assess the effect of immigrants on natives' labour market outcomes. Both refer to a period earlier than 1996, when immigration was a less relevant phenomenon in Italy. More in details, Gavosto et al. (1999) regress the mean wage of a specific industrial sector in a given region, conditional on a vector of individual characteristics, on the share of foreign workers in the same industry and geographical area.

\footnotetext{
${ }^{21}$ For a comprehensive review of the existing studies on the labour market effect of immigration see Dustmann et al. (2016).
} 
The total effects on natives' wages are never significant. Similarly, Venturini and Villosio (2006) estimate separate regressions for industry-region specific groups to evaluate the marginal effect of immigrants on the conditional probability of being unemployed. Results are puzzling and heterogeneous, since they also change across years, showing some competion between natives and immigrants at the end of the period. Centralised wage bargaining, still very relevant during the years of the study, could have attenuated any effect of migrant inflows on native wages.

A more recent work add evidence to the debate on the wage effect of immigration in Italy. According to the results by Staffolani and Valentini (2010), immigrants never reduced native wages across sectors and regions during the years 1995-2004. Natives' wages are also regressed on the overall variation of immigrants at the regional level. According to Dustmann et al. (2016), this total effect is expected to be more negative, since a pure spatial approach does not consider the complementarity between different workers. Surprisingly, the estimated positive coeffients are instead larger for all groups of workers.

A serious caveat is associated with all the aforementioned studies as none of them convincingly address the endogenous allocation of immigrants workers across geographical areas or industrial sectors. Therefore, the results might be biased and must be considered only as descriptive of the stylized facts characterizing Italian immigration. More recently, Brunello et al. (2020) find that immigration has reduced avarage wages, mainly for low-skilled workers, and has benefited manufacture firms.

Assuming factor price equalization, the other two adjustment channels of the labour market_-pointed at by Hanson and Slaugther (2002)—have to be assessed. Some papers have analysed the potential impact of immigrants on the Italian production structure. De Arcangelis et al. (2015) - in a study of the Italian provices (NUTS3) from 1995 to 2006 - find a positive effect of the share of immigrant workers on the value added of the manufacture relatively to services. A cross-sectional analysis on the manufacture sector only, developed by Bettin et al. (2014), indicates that a larger share of foreign workers is associated with an increase in the output of firms using relatively more labour-intensive production technologies. Etzo et al. (2017) analyse the evolution of the value added per workers of the manufacturing sector. Using data on Italian provinces for the period 2008-2011, they conclude that - at least in a subset of manufacture sectors - an increase in immigration induced an increase in value added per capita, mainly due to an increase of total factor productivity. Differently, Bratti and Conti (2018) do not find any positive effect of immigration on firms' innovation in terms of new patents.

According to the Heckscher-Ohlin framework, international trade flows are substitutes to international movement of production factors. Nonetheless, there is evidence of complementarity between the two phenomena (see e.g. Metulini et al., 2018). This has been documented also for the Italian provinces between 2002 and 2009. Bratti et al. (2014) show that both exports and imports display a positive elasticity to immigration.

The large share of immigrants involved in the provision of personal services might affect households' behaviuor by complementing or substituting the time allocated to non market activties by natives household member. The increase in the 
supply of markateble household services can affect the labour supply of household memebrs, especially of women, and their fertily decision.

Two papers investigated the link between immigrants provision of personal services and native female labour supply. Barone and Mocetti (2011) show that an increase in the number of immigrant women employed in household services increases the hours worked by native women already employed. This effect is present only for high-skilled women and for those more involved in housekeeping duties-i.e., women with children under 3 years old or living in households with old members. Peri et al. (2015) find also that women over 55 with old persons at home delay their retirment decisions in areas where the supply of immigrant services is higher.

More recently, Mariani and Rosati (2021) looked at the impact of the increase of marketable household services on the fertility of native women. Exploting the natutral experiment of the unexpected opening to immigrants from the "new" EU countreis in 2007, they show the increase in the inflows from Romania of women specialzing in household services generated an increase in the fertility rate of non negligible size.

\section{Summary and Conclusions}

We have presented evidence about the main dimensions and characteristics of immigration in Italy in the recent past and reviewed the analytical work aimed at understanding and interpreting the impact of the phenomenon. In this concluding section we briefly discuss the main gaps in knowledge that have emerged from our review.

In terms of location, we have seen that immigrants tend to reside in relatively better off areas, where also natives tend to move. However, the network effects appear to be rather relevant leading to a certain degree of geographical segregation between natives and migrants and an even stronger segregation of immigrants by ethnic group. There is evidence that the arrival of immigrants tends to crowd out the movement of natives, especially of the low-skilled ones. The evidence, however, is rather dated and does not discuss the implications of this crowding out for the welfare of natives.

Other dimensions of integration (a part for education, discussed below) have not been discussed in the literature leaving a wide gap to be filled. Aspects like housing prices and congestion in the use of public goods remains largely unexplored. Little evidence is available in terms of wage discrimination. It appears that the wage distribution of second-generation immigrants tends to converge to that of natives, albeit the process of convergence might have slowed down in the recent past. On the other hand, first-generation immigrants appear to be relatively more disadvantaged.

Human capital is the best explored area, with results indicating a persistent but relatively small gap of immigrant children with respect to natives, persisting after controlling for background characteristics. However, as immigrants are disproportionately present in the less favoured groups of the population the learning gap remains on average substantial. The impact on native peers appears on average to be limited, but it raises when in the classroom there are many immigrants present and 
the whole group of students (natives and immigrants) is relatively low performing. While the evidence is rather solid in this area, the policy implications have not been developed nor many programs have been rigorously evaluated.

The impact of immigrants on labour market outcomes of natives and on the characteristics of production, that has been at the center of the policy debate and of the academic research, is little explored. Available results for Italy are scant, dated and affected by methodological problems. While international evidence can offer a guide to the likely impact of immigrants, the external validity of many of the results available in the academic literature remains questionable given also that the labour market and the productive structure of Italy differ substantially from that of the country case most widely analyzed. There is, therefore, a large knowledge gap to be filled in an area that is highly important for the policy debate.

A relatively large share of the immigrants, especially women, work in the provision of household services. The increase in the supply of domestic marketable services is like to affects both the allocation of time of the domestic provider of those services-inflencing labour supply and fertility decision-and the outcomes of the recipients of these services-mainly children and elderly. These are areas of obvious importance, also in the ligth of the recent pandemic, for which the evidence is really scarse.

Finally, the impact of immigrations on public finances is broadly discussed but no studies have addressed this aspect for Italy, ${ }^{22}$ while some results are available for the US, and some Eurpoean countries. ${ }^{23}$

A general comparison with other receiving countries is complex, since an analysis similar to that carried out in this paper is missing in the literature. It is, therefore, difficult to assess general differences or similarities if we have to rely on scattered results, produced on different periods, datasets and methodologies.

The evidence available for Italy certainly does not match the policy relevance of an issue that has been dominating the public debate in the recent years. Moreover, if taken at face value, the evidence for Italy does not lead to any conclusion alarming enough to justify the concerns present in the society at large. Therefore, either the analysis of the economic consequences of immigration is not the relevant dimension to focus on or it has not addressed some very relevant issues. Likely both aspects are to some extent true. On the one hand, concerns about factors like cultural identity, fear of crime ${ }^{24}$ appear to play a very important role, on the other hand aspects like the "optimal" number of immigrants, the differential impact on public services, or house prices have not been addressed.

As a final remark this review shows how, beside the specific case of Italy, from the current literature, it is difficult to get a picture of the characteristics and impact of immigration in a country detailed enough to guide effective policy interventions.

\footnotetext{
22 With the only exception of Pellizzari (2013) that looks at a very specific aspect of the topic.

23 For a survey see Rowthorn (2008).

24 see e.g. Bianchi et al. (2012).
} 


\section{Appendix A: Data Sources}

\section{Administrative Data on Resident Population}

Administrative data are collected by local statistical offices and elaborated by Istat every year since 2002. The unit of observation is the municipality-the lowest local administrative unit (LAU2).

\section{Labour Force Survey}

The Labour Force Survey is collected quartely and is representative of the main characteristics of the labour force at provincial level (NUT3).

\section{Naturalizations}

Registered by the Italian Ministry of the Interior and elaborated by Istat. The unit of observation is the individual, but data are available at the province level (NUTS3). Annual naturalizations by province are disaggregated according to the reason of naturalization-Residence, Marriage, Others.

\section{Personal Incomes}

Individual tax returns are collected by the Italian Ministry of Economics and Finance every year since 2012. Data are aggregated at the municipal level and they include individual income, as well as total profits by small businesses.

\section{Standardized Learning Test}

The National Institute for the Evaluation of the Education and Training System (INVALSI) submits, each year since 2011, standardized tests to children in different educational levels in all the italian schools. The tests are accompanied by some questions on children socio-economic background and on demographic information including Country of origin and parents' Country of origin (Tables 15, 16). 


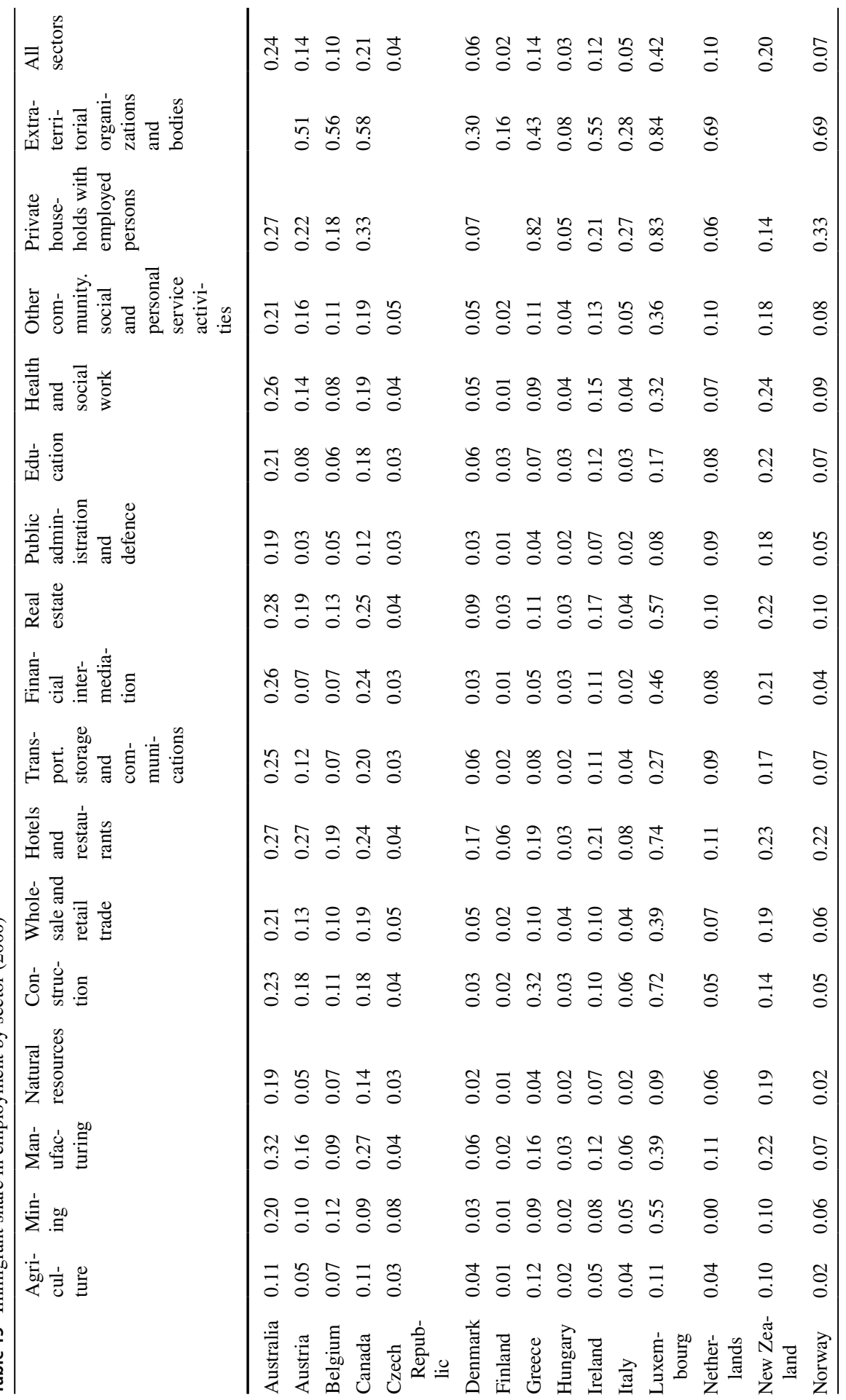




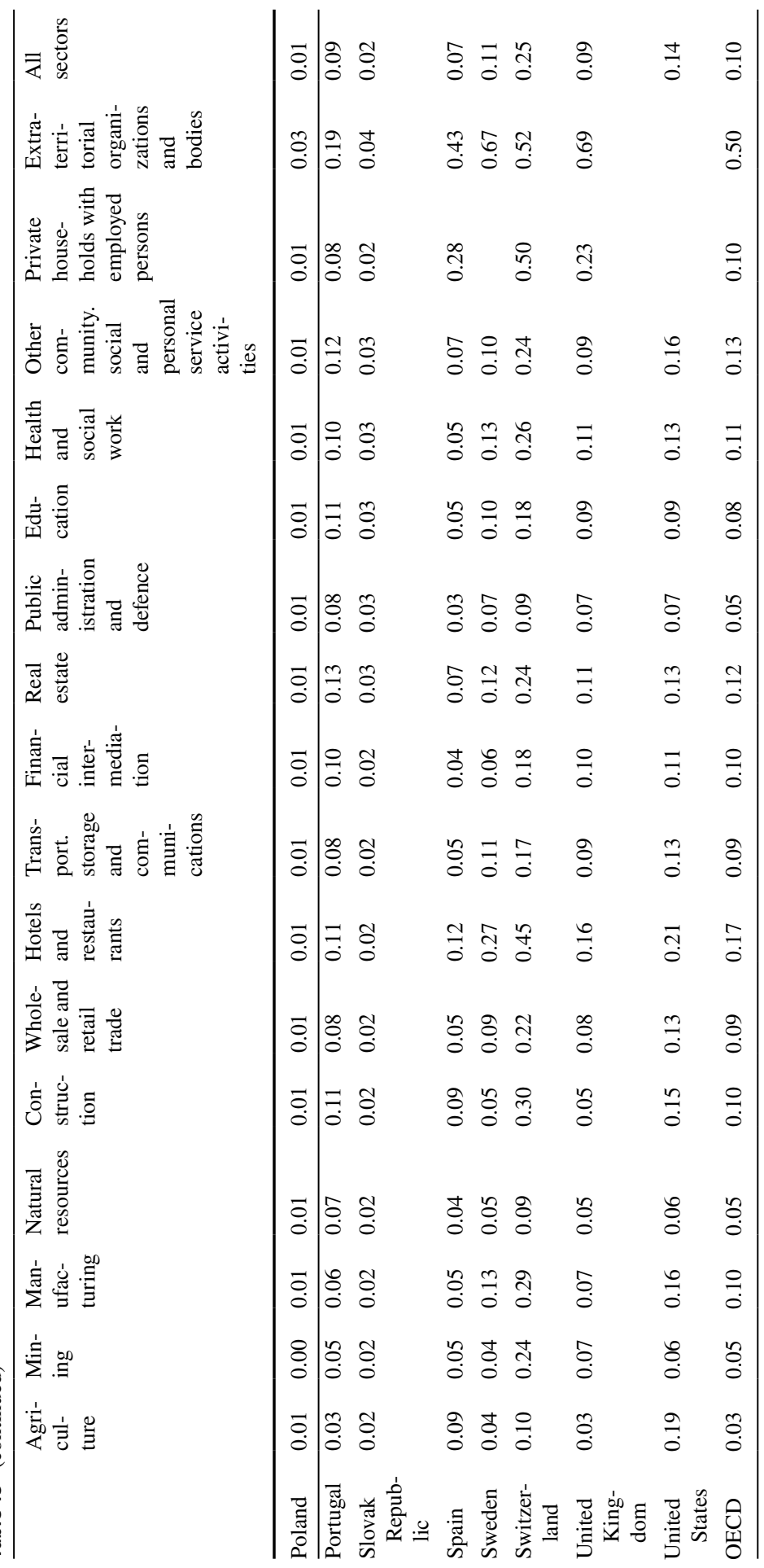




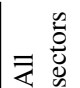

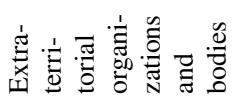

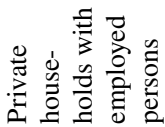

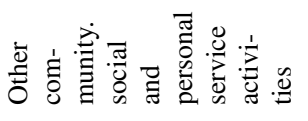 \\ 窇焉焉 \\ 点}

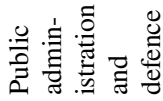

ॠँّ

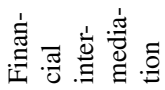

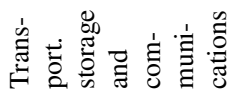

总密芯芯

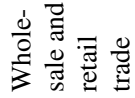

ఠิ

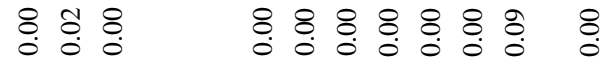

$\stackrel{8}{8}: \stackrel{0}{0}:$

ț

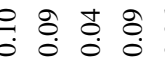

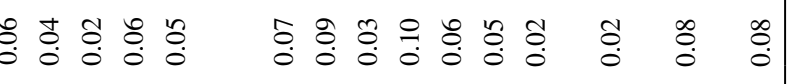

苛

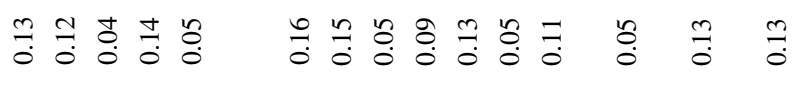

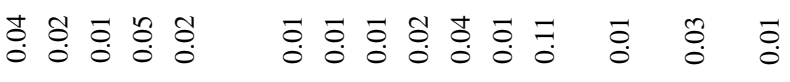

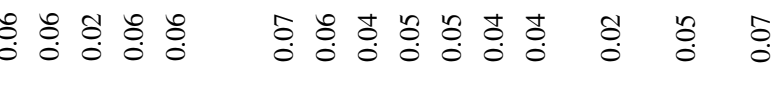

采

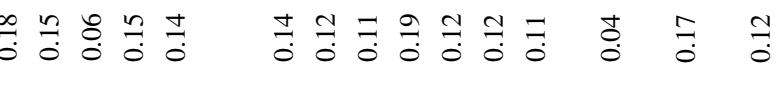

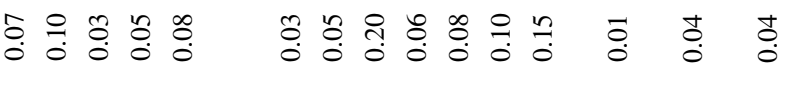

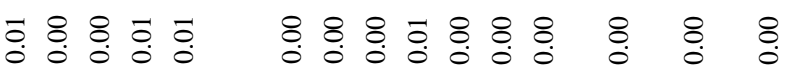

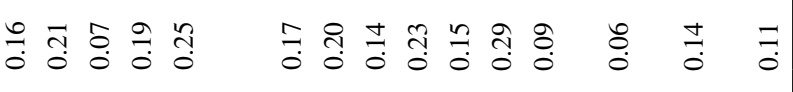

ஏ둥

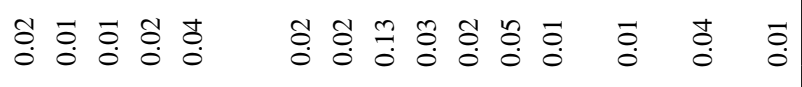

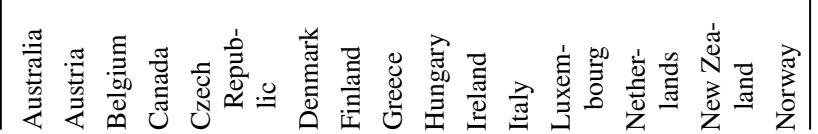




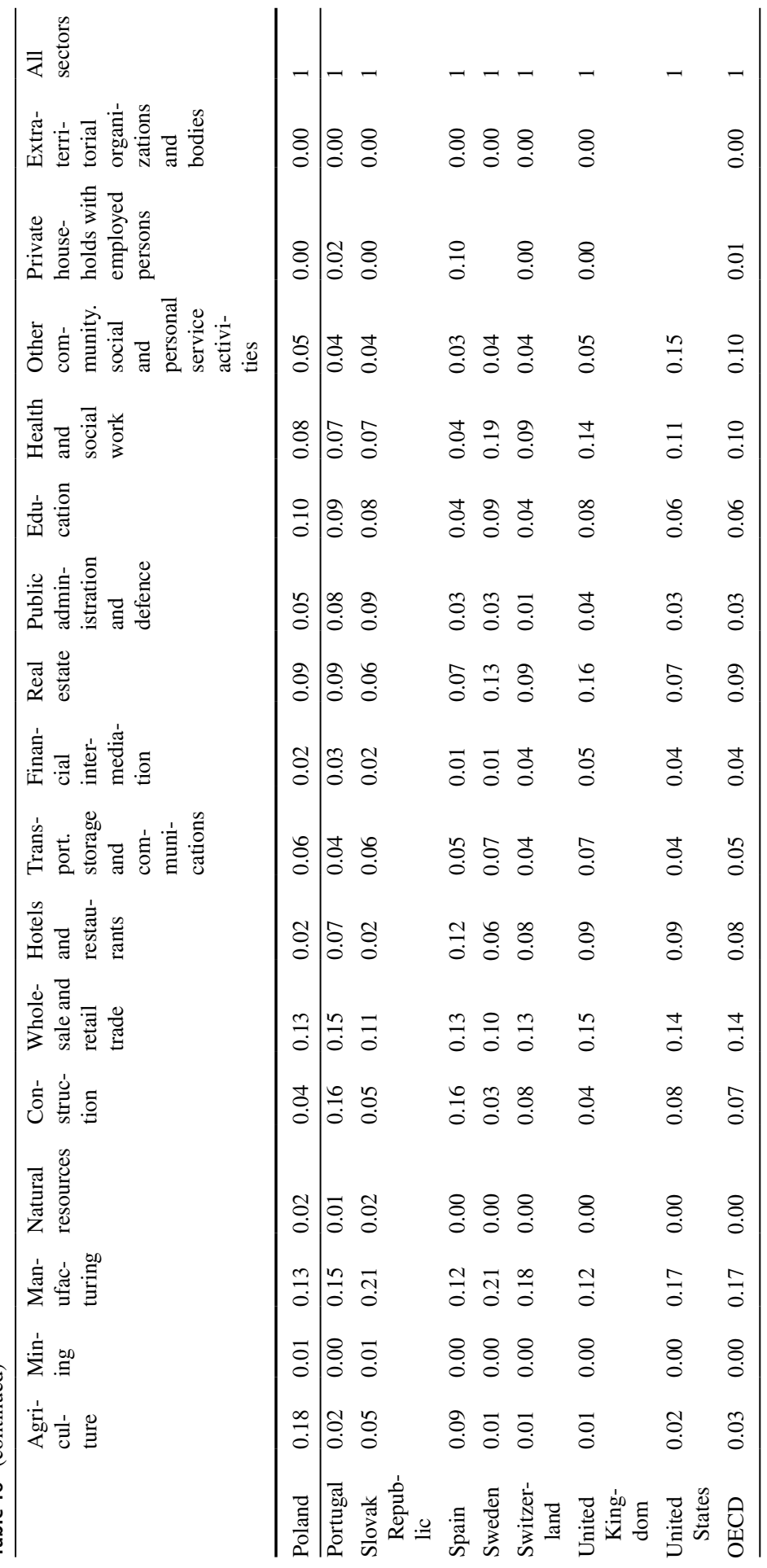


Acknowledgments We are very grateful to Çaglar Özden, Michał Rutkowski, Paolo Verme, Gian Carlo Blangiardo, Tommaso Frattini and Gaetano Basso for their useful comments. A slightly different version of this paper has been presented to the Joint Workshop on Applied Economics (Moscow, 2019), the Workshop on Demographic Change and Labor Mobility (Rome, 2019) and the workshop on "L'Immigrazione in Italia: I Dati e gli Attori Istituzionali" (Rome, 2019). We declare that the manuscript entitled "The Immigration Puzzle in Italy. A survey of Evidence and Facts" has not been submitted or published elsewhere. We declare that we do not have received any fundings and that none of the authors has a conflict of interest with the topic of the paper.

Funding Open access funding provided by Università degli Studi di Roma Tor Vergata within the CRUICARE Agreement.

Open Access This article is licensed under a Creative Commons Attribution 4.0 International License, which permits use, sharing, adaptation, distribution and reproduction in any medium or format, as long as you give appropriate credit to the original author(s) and the source, provide a link to the Creative Commons licence, and indicate if changes were made. The images or other third party material in this article are included in the article's Creative Commons licence, unless indicated otherwise in a credit line to the material. If material is not included in the article's Creative Commons licence and your intended use is not permitted by statutory regulation or exceeds the permitted use, you will need to obtain permission directly from the copyright holder. To view a copy of this licence, visit http://creativecommons.org/licen ses/by/4.0/.

\section{References}

Adamopoulou E, Kaya E (2019) Not just a work permit: EU citizenship and the consumption behavior of documented and undocumented immigrants. IZA Discussion Paper No. 12642

Ballatore RM, Fort M, Ichino A (2018) Tower of Babel in the classroom: immigrants and natives in Italian schools. J Law Econ 36(4):885-921

Barban N, White MJ (2011) Immigrants' children's transition to secondary school in Italy. Int Migr Rev 45(3):702-726

Barone G, Mocetti S (2011) With a little help from abroad: the effect of low-skilled immigration on the female labour supply. Labour Econ 18(5):664-675

Barone G, D'Ignazio A, de Blasio G, Naticchioni P (2016) Mr. Rossi, Mr. Hu and politics. The role of immigration in shaping natives' voting behavior. J Public Econ 136:1-13

Basile R, De Benedictis L, Durban M, Faggian A, Mínguez R (2021) The impact of immigration on the internal mobility of natives and foreign-born residents: evidence from Italy. Spat Econ Anal 16(1):9-26

Basso G, D’Amuri F, Peri G (2019) Immigrants, labor market dynamics and adjustment to shocks in the Euro Area. IMF Econ Rev 67(3):528-572

Bertolini P, Lalla M, Pagliacci F (2015) School enrolment of first-and second-generation immigrant students in I taly: a geographical analysis. Pap Reg Sci 94(1):141-159

Bettin G, Lo Turco A, Maggioni D (2014) A firm level perspective on migration: the role of extre-EU workers in Italian manufacturing. J Prod Anal 42:305-325

Bianchi M, Buonanno P, Pinotti P (2012) Do immigrants cause crime? J Eur Econ Assoc 10(6):1318-1347

Borjas GJ (1992) Ethnic capital and intergenerational mobility. Q J Econ 107(1):123-150

Bratti M, Conti C (2018) The effect of immigration on innovation in Italy. Reg Stud 52(7):934-947

Bratti M, De Benedictis L, Santoni G (2014) On the pro-trade effects of immigrants. Rev World Econ 150(3):557-594

Brücker H, Fachin S, Venturini A (2011) Do foreigners replace native immigrants? A panel cointegration analysis of internal migration in Italy. Econ Model 28(3):1078-1089

Brunello G, Lodigiani E, Rocco L (2020) Does low-skilled immigration increase profits? Evidence from Italian local labour markets. Region Sci Urban Econ 85:103582

Brunello G, De Paola M (2017) School segregation of immigrants and its effects on educational outcomes in Europe. In: EENEE Analytical Report No. 30. European Commission. 
Cadena BC, Kovak BK (2016) Immigrants equilibrate local labor markets: evidence from the great recession. Am Econ J Appl Econ 8(1):257-290

Campo F, Giunti S, Mendola M (2020) The political impact of refugee migration: evidence from the italian dispersal policy. In: University of Milan Bicocca Department of Economics, Management and Statistics Working Paper, (456).

Ceccarelli C, Giorgi GM, Guandalini A (2014) Is Italy a melting pot?. Rivista Italiana di Economia Demografia e Statistica 68(3/4).

Contini D (2013) Immigrant background peer effects in Italian schools. Soc Sci Res 42(4):1122-1142

Cozzolino M, Di Porto E, Martino EM, Naticchioni P (2018) (2018) Gli immigrati nel mercato del lavoro italiano: uno sguardo all'universo dei lavoratori dipendenti 1995-2015. Economia Italiana 1:35-72

D’Agostino A, Regoli A, Cornelio G, Berti F (2016) Studying income inequality of immigrant communities in Italy. Soc Indic Res 127(1):83-100

dalla Pellegrina L, Saraceno M, Suardi M (2018) Migration policy: did an emergency provision displace standard rules? Evidence from Italy. Economia Politica 35(3):863-893

De Arcangelis G, Di Porto E, Santoni G (2015) Migration, labor tasks and production structure. Reg Sci Urban Econ 53:156-169

Dell'Aringa C, Pagani L (2011) Labour market assimilation and over-education: the case of immigrant workers in Italy. Economia Politica 28(2):219-240

Di Liberto A (2015) Length of stay in the host country and educational achievement of immigrant students. Int J Manpow 36(4):585

Dustmann C, Schönberg U, Stuhler J (2016) The impact of immigration: why do studies reach such different results? J Econ Perspect 30(4):31-56

Etzo I, Massidda C, Mattana P, Piras R (2017) The impact of immigration on output and its components: a sectoral analysis for Italy at regional level. Economia Politica 34(3):533-564

Fellini I, Guetto R, Reyneri E (2018) Poor returns to origin-country education of non-western immigrants in Italy: an analysis of occupational status on arrival and mobility. Soc Inclus 6(3):34-47

Frattini T, Campa P (2019) 4th migration observatory report: "Immigrant Integration in Europe." Centro Studi Luca d'Agliano and Collegio Carlo Alberto Publishing, Milan

Frattini T, Meschi E (2019) The effect of immigrant peers in vocational schools. Eur Econ Rev 113:1-22

Fullin G, Reyneri E (2011) Low unemployment and bad jobs for new immigrants in Italy. Int Migr 49(1):118-147

Gavosto A, Venturini A, Villosio C (1999) Do immigrants compete with natives? Labour 13(3):603-621

Hanson GH, Slaughter MJ (2002) Labor-market adjustment in open economies: evidence from US states. J Int Econ 57(1):3-29

Levi E, Mariani RD, Patriarca F (2020) Hate at first sight? Dynamic aspects of the electoral impact of migration: the case of Ukip. J Popul Econ 33(1):1-32

Mariani RD, Rosati FC (2021) Immigrant supply of marketable child care and native fertility in Italy (No. 745). GLO Discussion Paper.

Mastrobuoni G, Pinotti P (2015) Legal status and the criminal activity of immigrants. Am Econ J Appl Econ 7(2):175-206

Metulini R, Sgrignoli P, Schiavo S, Riccaboni M (2018) The network of migrants and international trade. Economia Politica 35(3):763-787

Mocetti S, Porello C (2010) How does immigration affect native internal mobility? New evidence from Italy. Reg Sci Urban Econ 40(6):427-439

Murat M (2012) Do immigrant students succeed? Evidence from Italy and France. Glob Econ J 12(3):185-269

OECD (2018) International migration outlook 2018. OECD Publishing, Paris

Pasquini A, Rosati FC (2019) A human capital index for the Italian Provinces. Mimeo.

Pellizzari M (2013) The use of welfare by migrants in Italy. Int J Manpow 34(2):155-166

Peri G (2016) Immigrants, productivity, and labor markets. J Econ Perspect 30(4):3-30

Peri G, Romiti A, Rossi M (2015) Immigrants, domestic labor and women's retirement decisions. Labour Econ 36:18-34

Rowthorn R (2008) The fiscal impact of immigration on the advanced economies. Oxf Rev Econ Policy 24(3):560-580

Staffolani S, Valentini E (2010) Does immigration raise blue and white collar wages of natives? The case of Italy. Labour 24(3):295-310

Tonello M (2016) Peer effects of non-native students on natives' educational outcomes: mechanisms and evidence. Empir Econ 51(1):383-414 
Venturini A, Villosio C (2006) Labour market effects of immigration into Italy: an empirical analysis 1. Int Labour Rev 145(1-2):91-118

World Bank (2018) Moving for prosperity: global migration and labor markets. Policy Research Report, Washington DC

Publisher's Note Springer Nature remains neutral with regard to jurisdictional claims in published maps and institutional affiliations. 